\title{
Kirpal Singh
}

\section{Water City Sky}

They intermingle interminably

Criss-crossing centuries

Cementing, commenting, conveying

History as conceived, perceived, lived.

The people they came and went

Some stayed, bred and occupied spaces -

Their children the inheritors of riches

As properties bloomed and soared.

All have now changed

Water and city and sky

Share a common breath

As they weave rainbows

And spread visions and missions.

I stand as witness and watch

Decades going by, rushing

Ends and means, Means and ends

Get confused, render a high cost

More sweat for rags to riches

More time for those who govern.

They say doctors cure and poems heal - 